\title{
THE SPILLOVER EFFECTS OF OUTWARD FOREIGN DIRECT INVESTMENT ON HOME COUNTRIES: EVIDENCE FROM THE UNITED STATES
}

\author{
by \\ Jitao Tang \\ Quantitative Economics and Statistics \\ Ernst\&Young LLP \\ Jitao.Tang@ey.com \\ and \\ Rosanne Altshuler \\ Department of Economics \\ Rutgers University \\ altshule@rci.rutgers.edu
}

This draft: January 4, 2015

\begin{abstract}
Most studies of foreign direct investment (FDI) spillovers focus on externalities of inward FDI to host country firms. However, spillovers may also be generated from outward FDI and flow to home country firms. We test for the presence of spillovers from U.S. multinational corporations to domestic U.S. firms in the same industry, downstream industries and upstream industries using firm level information from Standard and Poor's Compustat data and industry level data on U.S. outward FDI from the U.S. Bureau of Economic Analysis. We find evidence of positive and significant spillovers flowing from multinational customers to their domestic suppliers. This is consistent with most previous studies of spillovers from inward FDI and may suggest a role for domestic policies that subsidize outward FDI. We also find that the presence of beneficial spillovers depends on several firm characteristics including exporting status, size and absorptive capacity.
\end{abstract}

Keywords: Foreign Direct Investment, Home Country Spillovers, Absorptive Capacity

We thank Estelle Dauchy, Timothy Goodspeed, Gal Hochman, Andrew Lyon, Thomas Prusa, Hilary Sigman, Matthew Slaughter and participants of the Oxford University Centre for Business Taxation Summer 2014 Symposium for helpful comments. 


\section{Introduction}

The operations of multinational companies (MNCs) are a concern to both home and host countries. Governments in developed and developing countries have adopted various policies to attract the activities of MNCs under the assumption that inward foreign direct investment (FDI) is beneficial to host countries. A long line of literature has examined the direct effects of inward FDI on the foreign subsidiaries of MNCs in host countries and the indirect spillover effects to domestic firms in the host economy. A relatively smaller body of work has examined the impact of multinational activities abroad on their domestic operations. The focus has, for the most part, been on the effect of a MNC's expansion abroad on its domestic employment and capital investment. ${ }^{1}$ The possibility that outward FDI may generate positive spillovers to other domestic firms not related to the MNC has been largely ignored. But these indirect benefits could potentially be larger than any benefit or cost to own country domestic subsidiaries of MNCs. Recent changes in the UK and Japan that removed home country taxation of foreign active earnings abroad of domestic MNCs likely reflect the view that outward FDI generates both direct and indirect benefits. In this paper, we attempt to measure spillovers of outward FDI in an attempt to both better understand the impact of investment abroad on home countries and inform the debate over appropriate government policy towards MNCs. If outward FDI generates significant direct and indirect positive externalities at home, a case may exist for subsidizing the foreign activities of home country MNCs.

We focus on productivity spillovers from FDI. A long line of research has established that more productive firms engage in FDI and that FDI itself is productivity-enhancing. ${ }^{2}$ Since MNCs often have

\footnotetext{
${ }^{1}$ Recent work includes the Desai, Foley and Hines (2009) study of the impact of the foreign activity of domestic U.S. MNCs on their home country activities. They find that greater foreign investment is associated with greater domestic investment and higher domestic employee compensation. Other recent papers exploring how the outward FDI of MNCs relates to their economic decisions at home include Barba Navaretti et al. (2010) (for France and Italy), Becker and Muendler (2010) (for Germany), Harrison and McMillan (2011) (for the United States) and Simpson (2012) (for the UK).

${ }^{2}$ Helpman et al. (2004) develop a theoretical model that suggests companies choose FDI over exports when they become more productive. Wagner (2006) and Arnold and Hussinger (2010) provide empirical evidence that companies engaging in FDI are more productive than purely domestic companies and companies that export. Almeida (1996), Fosfuri and Motta (1999), Chung and Alcácer (2002), and Wagner (2011) show MNCs also obtain improvements in productivity through their foreign activities.
} 
close business relationships with domestic firms in their home countries, productivity-enhancing knowledge obtained from engaging in FDI may spillover to domestic firms. We test for the presence of spillovers from U.S. MNCs to domestic U.S. firms in the same industry, downstream industries and upstream industries using firm level information from Standard and Poor's Compustat data and industry level data on U.S. outward FDI from the U.S. Bureau of Economic Analysis.

The transmission channels for home country productivity spillovers are similar to those between foreign MNCs and host country firms that have been discussed in the extant literature on inward FDI. Employees may obtain superior skills as a result of overseas experience (either directly or indirectly) and transfer these skills to future domestic employers through labor mobility (Fosfuri et al. 2001, Glass and Saggi 2002, and Poole 2006). Domestic competitors of MNCs may be forced to become more efficient if FDI undertaken by MNC rivals leads to enhanced productivity. MNCs may bring more advanced managerial strategies acquired abroad to their home market creating an opportunity for domestic firms to learn through observation and imitation (Das 1987 and Wang and Blomström 1992). At the same time, however, MNCs have an incentive to prevent knowledge from leaking to competing domestic firms in the same industry. This may explain the failure of researchers to detect positive intra-industry spillovers, or "horizontal spillovers", in studies of the impact of inward FDI on host country firms (Kathuria 2000, Barrios and Strobl 2002, and Castellani and Zanfei 2003).

MNCs have no incentive, however, to prevent spillovers from occurring through the supplierclient relationship, also known as “vertical spillovers”. For example, MNCs entering foreign markets may require their intermediate input suppliers to produce and deliver inputs in a more efficient manner. To ensure high quality and on-time delivery of the inputs, MNCs may provide direct assistance to their suppliers. Furthermore, the demand for intermediate inputs from home country suppliers may increase when MNCs successfully tap the foreign market and expand production abroad. The resulting increase in demand provides domestic intermediate input producers an opportunity to take advantage of economies of scale lowering costs and improving productivity.

An example of vertical spillovers is illustrated in the case study of Proctor \& Gamble (P\&G) and 
Appleton Papers in Slaughter (2013). Around 2000, P\&G was seeking a technology called microencapsulation that integrates perfumes into washing detergent and dryer softeners as P\&G's customers in many foreign countries favor such products. To do this, $P \& G$ initiated a supplier partnership with Appleton Papers which had decades of experience in microencapsulation in the industry of carbonless paper to develop the technology to produce performed microcapsules (PMCs). P\&G sent researchers to Appleton to provide technical assistance, invested in R\&D of Appleton’s microencapsulation division, and brought a substantial growth opportunity for Appleton. After partnering with P\&G, Appleton expanded production and employment significantly to supply the needed PMCs. This type of inter-industry spillover from MNCs to their suppliers is referred to as a "backward spillover". "Forward spillovers", on the other hand, occur when firms benefit from being customers of MNCs. This type of inter-industry spillover occurs when advanced technologies assimilated by the affiliates of MNCs in foreign countries are transferred to their home country customers through the supply of intermediate inputs.

A large literature has studied spillovers from MNCs to domestic firms in host countries (see Smeets 2008 for a review). A series of recent studies have found supportive evidence of backward spillovers (Javorcik 2004, Kugler 2006, and Javorcik and Mariana 2008). Our work complements the literature by examining whether the FDI undertaken by home country MNCs generates productivity enhancing spillovers to home country firms. In addition to measuring spillovers from domestic MNCs to home country firms, we also explore the conditions under which positive spillovers are likely to occur. We investigate several characteristics of home country firms that might play a critical role in their benefiting from positive spillovers, including exporting status, firm size and absorptive capacity. We find significant and positive spillovers from multinational customers to the productivity of their suppliers (backward spillovers). Moreover, we provide evidence that exporting and small firms are more likely to benefit from backward spillovers. We find no evidence of spillovers from FDI of home country MNCs to domestic firms in the same industry (horizontal spillovers) or upstream industries (forward spillovers). However, when we take the absorptive capacity of domestic recipients into account, we find that firms 
distributed at the two ends of the productivity spectrum are more likely to receive both horizontal and backward spillovers from FDI undertaken by home country MNCs.

The remainder of the paper is organized as follows. We briefly review the literature on host country and home country spillovers in the next section. Section 3 discusses the data and empirical strategy we use to measure FDI spillovers generated by U.S. MNCs on domestic firms. Section 4 provides our main results and section 5 concludes.

\section{Literature Review}

\subsection{FDI Spillovers on the Host Economy}

Early studies of FDI mostly focused on how the presence of foreign MNCs may impact a host nation economy. Researchers have put forward a variety of theories to explain how positive externalities might be generated from foreign to domestic firms. The theoretical models posit three potential transmission channels for intra-industry, or horizontal, spillovers. Das (1987) and Wang and Blomström (1992) describe a "demonstration" channel in which domestic firms learn productivity enhancing practices from foreign firms that enter the market through observation and imitation. This learning may occur both at the production level when manufacturing processes are imitated through reverse engineering and at the management level when foreign firms' marketing and managerial strategies are observed.

Fosfuri et al. (2001), Glass and Saggi (2002) and Poole (2006) consider labor mobility as a potential channel for intra-industry spillovers. In these models, local production workers and managerial staff in a MNC's subsidiary in the host country receive training to apply superior technology to local production. Domestic competitors have an incentive to hire these trained employees and positive spillovers occur when the MNC fails to provide a sufficient wage premium to retain its highly trained employees. The difficulty of tracking workers is a major obstacle for researchers attempting to detect externalities from this channel in empirical studies.

The third channel through which domestic firms may benefit from inward FDI is competition. 
Competition from foreign firms pressures indigenous rivals to update technology and production processes. Even if domestic firms are unable to update their production technology, they will be forced to use existing resources more efficiently so as to compete with the more advanced foreign firms (Glass and Saggi 2002 and Markusen and Venables 1999). The competition effect may also generate negative externalities to local firms when incoming foreign firms take over a large share of the market and drive local firms out of business.

The possibility that foreign firms bring not only new investment but also secondary spillovers which result in higher productivity growth to host nations has led many economists to search for empirical evidence of spillovers. The pioneering studies of Caves (1974) and Globerman (1979) provide positive evidence that indigenous firms’ productivity in Australia and Canada, respectively, coincide with higher shares of foreign subsidiaries, although their conclusions are limited by their crude measure of foreign presence and the poor quality of data. Following this early work, economists extended empirical tests of FDI spillovers to a larger set of countries including those with developing and transition economies. However, due to a number of factors including use of improper statistical methods, the heterogeneity of spillovers and the lack of comprehensive firm-level data, researchers have found mixed results.

Görg and Greenaway (2004) provide a comprehensive review of recent studies of intra-industry FDI spillovers and pay particular attention to work with panel data at the firm level. As Görg and Strobel (2001) argue, cross-sectional panel data are most appropriate for this type of study since they allow researchers to study domestic productivity over a longer period and allow for a potentially rich set of controls as well as industry and country specific fixed effects.

To highlight the mixed nature of the findings from cross-sectional panel studies of intra-industry (horizontal) spillovers consider the following set of papers. Kathuria (2000) finds that the presence of foreign firms in India is associated with negative intra-industry spillovers in sectors where foreign-owned firms are close to the technological frontier. Castellani and Zanfei (2003) provide evidence of positive spillovers in Italy, negative spillovers in Spain and no evidence of horizontal spillovers in France. Barrios 
and Strobl (2002) find that FDI spillovers only occur to domestic Spanish firms with an appropriate level of absorptive capacity. Keller and Yeaple (2009) show that multinationals generate statistically significant productivity benefits to domestic firms in the same industry using U.S. firm level data and a measure of total factor productivity. After reviewing forty studies of intra-industry productivity spillovers, Görg and Greenaway (2004) suggest that researchers pay more attention to the conditions affecting the likelihood of positive FDI spillovers, including the form of entry (green field or acquisition), local economic environment and investment incentives provided by host governments.

More recent studies of FDI spillovers have focused on evaluating the factors which induce externalities. Researchers have paid close attention to the hypothesis that knowledge and technology spillovers are more likely to be found in vertical linkages between suppliers and clients in different industries than between competitors in the same industry. Vertical spillovers might be more common than horizontal spillovers since MNCs that bring superior skills in production and management to host countries will typically try to prevent these advantages from flowing to local competitors. MNCs are willing, however, to provide assistance to their local suppliers so as to ensure high quality and on-time delivery of inputs. Foreign firms may also bring higher-quality products that can be used as intermediate inputs by their local customers in downstream sectors. Rodriguez-Clare (1996) provides theoretical support to the notion of vertical spillovers. His model suggests that when transportation and communication costs are high, vertical spillovers from multinational customers to local suppliers are more likely to materialize.

Researchers generally have been more successful finding empirical evidence of vertical spillovers, especially backward spillovers, than horizontal spillovers. For instance, Javorcik (2004), Liu (2008) and Blalock and Gertler (2008) all find statistically significant evidence of backward spillovers --that local firms obtain productivity gains from supplying foreign firms --- but no statistically significant evidence of horizontal spillovers.

More recent work has recognized that the characteristics of the local firms can play an important role in determining the extent (if any) of positive externalities from FDI. Domestic firms are 
heterogeneous and, as a result, all firms are not likely to benefit equally from FDI. Barrios and Strobl (2002) show that, because of their exposure to international competition, exporting firms are more likely to absorb foreign technology and enjoy positive spillovers than non-exporting firms. Keller and Yeaple (2009) provide evidence that firms in high-tech industries with intensive R\&D activities receive stronger spillovers. They find no significant spillovers flowing to low-tech firms.

A firm's ability to internalize knowledge created by others and therefore benefit from spillovers may depend on its distance from the technological frontier. Wang and Blomström (1992) have argued that the greater the gap between a firm's own technology and the technological frontier in its industry, the larger the potential for the firm to benefit. Kokko et al. (1996) posit that the gap cannot be too wide since domestic firms need some basic skills to assimilate foreign knowledge. In contrast, Kolasa (2008) argues that firms near the technology frontier have greater absorptive capacity and are more capable of adopting transferred advanced technology. Empirical work finds that the effect of absorptive capacity on productivity may not be linear. Girma and Görg (2005) and Girma (2005) use nonlinear econometric methods and show that there is some threshold of absorptive capacity beyond which spillovers become stronger.

\subsection{FDI Spillovers on the Home Economy}

Firms may invest abroad in an attempt to access the advanced technology and managerial skills in foreign countries (Dunning and Narula 1995). Fosfuri and Motta (1999) develop a model in which laggard firms use foreign affiliates to acquire location-specific knowledge. The knowledge captured through FDI and transferred home may leak out to other competing firms in the home country and generate positive intra-industry spillovers through labor mobility and competitive forces, as in the case of inward FDI. In addition, the same forces leading to backward and forward spillovers on home country firms may operate with outward FDI. As a result, outward as well as inward FDI may create positive externalities. Externalities flow to domestic firms in the home country in the former case and in the host country in the latter case. But the transmission channels can be similar. 
While policies aimed at attracting FDI are prevalent, especially in developing countries, policies promoting outward FDI are relatively rare. ${ }^{3}$ This is likely because the effects of outward FDI on home economies are the subject of debate and, for the most part, policy makers and the public tend to focus their attention on potential negative impacts. Outward FDI, while certainly beneficial to investing firms, may also shift capital, tax revenues and employment opportunities abroad. ${ }^{4}$

Unlike its voluminous host country counterpart, the literature on spillovers from outward FDI is small. Most of the limited work examines OECD countries since developing countries are seldom a major source of FDI. Braconier et al. (2001) and Globerman et al. (2000) study the case of Swedish firms. The former study finds no correlation between labor productivity in Sweden and outward FDI using Swedish firm-level data while the latter suggests that domestic Swedish firms' likelihood of citing patents is positively affected by Swedish outward FDI. Castellani and Zanfei (2006) study outward FDI in Italy and find important external effects of an expansion of domestic multinationals on both employment and productivity of other domestic firms in Italy. Driffield et al. (2009) find positive spillovers of outward FDI on home country productivity but the data is at the industry level and the authors do not distinguish between domestic-owned and foreign-owned firms in the analysis. Vahter and Masso (2007) use enterprise-level data of Estonia. Their results demonstrate that the productivity of parent firms which establish affiliates abroad is positively correlated with outward FDI activities, although no evidence of sector-wide spillovers is found for other purely national firms in Estonia. Slaughter (2012) examines the impact of US MNCs on investment, employment and R\&D activities in the United States through the supply network using a number of case studies. No researchers that we are aware of, however, have empirically tested for the presence and size of productivity spillovers from U.S. MNCs to domestic U.S. firms. This paper carries out an empirical test to fill this gap.

\footnotetext{
${ }^{3}$ Developing countries that have official policies or organizations that provide assistance to domestic outward investing firms include China, India, Thailand and South Africa.

${ }^{4}$ See Kokko (2006) for a review of recent studies on the home country effect of outward FDI in developed economies and Globerman and Shapiro (2008) for outward FDI in emerging markets.
} 


\section{Data and Regression Strategy}

The main data for our study come from two sources. Firm level data are from Standard and Poor's Compustat North America database which provides comprehensive information on publicly traded firms in the U.S. and Canada. Industry level data on U.S. outward FDI activities are from the Bureau of Economic Analysis (BEA). We use these two sources of data to obtain firm level estimates of total factor productivity (TFP) for U.S. domestic firms and construct a measure of outward FDI activities in manufacturing industries (3111-3399) at the 4-digit NAICS industry level. We focus on the years 1999 to 2009 since the BEA changed its industry classification from SIC to NAICS in 1999. Our firm-level estimates of TFP and measures of outward FDI activities allow us to test for evidence of productivity spillovers from U.S. outward FDI to domestic U.S. firms. We provide details on the definition and construction of the variables in the appendix.

Although the Compustat dataset has detailed income statement and balance sheet information, it does not provide information on foreign ownership. To focus on purely domestic U.S. firms, we delete firms that either are incorporated or have headquarters outside the U.S. in order to remove firms that may be MNCs themselves. In addition, we drop firms that either have foreign pretax income or have income taxes payable to foreign governments during the sample period. ${ }^{5}$ Observations with missing values of employment, capital and value added are also deleted. Due to the panel structure and the estimation method adopted below, we also delete firms that have gaps in the sample period and those that appear in the sample for only one year.

Our focus is on spillover effects from outward FDI on domestic firm productivity. However, Compustat does not report a firm's TFP. We construct TFP as the Solow residual from estimating a CobbDouglass production function:

$$
y_{i t}=\alpha_{0}+\alpha_{l} l_{i t}+\alpha_{k} k_{i t}+\omega_{i t}+\eta_{i t}
$$

\footnotetext{
${ }^{5}$ One caveat to note is that this deletion may remove firms from the sample that only have warehouses abroad and receive income from the warehouse. These firms do not engage in FDI and should be included in the sample. Unfortunately there is no method to identify whether we are over-deleting firms in this way.
} 
where $y_{i t}$ is the log of a firm's value added, $l_{i t}$ is the log of the number of employees, $k_{i t}$ is the log of the firm's capital stock, $\omega_{i t}$ is a transmitted component that is observed by decision-makers but not the econometrician, and $\eta_{i t}$ is an i.i.d. shock. Since $\omega_{i t}$ affects firms' input decisions, simple OLS will generate biased estimates on labor and capital if the econometrician fails to recognize that a positive productivity shock leads to higher variable input.

To address the problem of the simultaneity of input choices, we apply the approach proposed by Olley and Pakes (1996) that accounts for not only simultaneity but also selection bias. Specifically, a firm will receive a liquidation value $\Phi$ if it chooses to exit the market and the firm maximizes its expected discounted value of future profits. The exit decision depends on whether current realization of $\omega_{i t}$ is less than some threshold $\underline{\omega}_{i t}\left(k_{i t}, a_{i t}\right)$ which is a function of capital stock $k_{i t}$ and firm's age $a_{i t} \omega_{i t}$ is assumed to follow a Markov process. If the threshold $\underline{\omega}_{i t}\left(k_{i t}, a_{i t}\right)$ is negatively related to capital stock as firms with higher capital stock have larger expected future profitability, then firms with small capital stock will exit the market. Such a selection process will lead to a downward bias on the coefficient on capital. To address the two problems, Olley and Pakes (1996) proposed assuming that investment $i_{i t}$ is a function of $\omega_{i t}, k_{i t}$ and $a_{i t}$ and is strictly increasing in $\omega_{i t}$. Then we can invert the investment function and write $\omega_{i t}$ as a function as follows

$$
\omega_{i t}=i^{-1}\left(i_{i t}, k_{i t}, a_{i t}\right)=h\left(i_{i t}, k_{i t}, a_{i t}\right)
$$

Consistent estimates of the coefficient on labor can be obtained from estimating the following equation with OLS since, after controlling for the unobserved shock, the error term is not correlated with inputs:

$$
y_{i t}=\alpha_{0}+\alpha_{l} l_{i t}+\phi\left(i_{i t}, k_{i t}, a_{i t}\right)+\eta_{i t}
$$

where $\phi\left(i_{i t}, k_{i t}, a_{i t}\right)=\alpha_{0}+\alpha_{k} k_{i t}+\alpha_{a} a_{i t}+h\left(i_{i t}, k_{i t}, a_{i t}\right)$. In the above equation $\phi\left(i_{i t}, k_{i t}, a_{i t}\right)$ is approximated by a second-order polynomial of $i_{i t}, k_{i t}$ and $a_{i t}$.

After obtaining a consistent estimate of the coefficient on labor, the next step is to estimate the following nonlinear equation: 


$$
y_{i t}-\hat{\alpha}_{l} l_{i t}=\alpha_{k} k_{i t}+\alpha_{a} a_{i t}+g\left(\hat{\phi}_{t-1}-\alpha_{k} k_{i, t-1}-\alpha_{a} a_{i, t-1}, \hat{P}_{i t}\right)+\xi_{i t}+\eta_{i t}
$$

where $\hat{P}_{i t}$ is the predicted probability of survival estimated from a Probit model. The Probit model is estimated on a second-order polynomial of capital, investment and age (lagged one period). In the above equation function $g$, which is similar to the inverse Mill's ratio in a two-step sample selection model, is also approximated by a second-order polynomial of $\hat{\phi}_{t-1}-\alpha_{k} k_{i, t-1}-\alpha_{a} a_{i, t-1}$ and $\hat{P}_{i t}$. This estimation technique corrects for the selection bias and gives consistent estimates of capital and age.

Using the Olley-Pakes method discussed above, we estimate labor and capital returns and predict TFP for each firm. Since different sectors do not necessarily have the same return to labor and capital, we allow the estimates to vary across the 2-digit NAICS sectors. The estimated return to labor and capital for NAICS sectors 31, 32 and 33 (Manufacturing) are reported in Table 1. As shown in the table, the return to labor is approximately 0.7 and the return to capital is approximately 0.3 . The sum of the two coefficients is close to 1 for all sectors, exhibiting nearly constant returns to scale.

TFP for each firm can be calculated using the estimated coefficients on labor and capital from Table 1. These TFP estimates are then regressed on some measure of outward U.S. FDI activities to examine the home country spillover effect. Equation (1) below shows an explanatory regression which is similar to those used in most early studies of FDI spillovers.

$$
\ln \operatorname{TFP}_{i j t}=\alpha+\beta \text { Horizontal }_{j t}+\alpha_{j}+\alpha_{t}+\varepsilon_{i j t}
$$

Horizontal $_{j t}$ is a proxy for outward FDI in industry $j$. It captures the extent of foreign activities by U.S. MNCs and is defined as the ratio of U.S. affiliate sales abroad in industry $j$ and domestic sales of industry $j$ in the U.S. market. $\alpha_{j}$ and $\alpha_{t}$ are industry and time dummies.

Equation (1) is estimated with Ordinary Least Squares (OLS) and the results are reported in column 1 of Table 2. According to the results in column 1, a U.S. domestic firm's productivity is positively correlated with U.S. outward FDI in the same industry. As discussed in Javorcik (2004), Liu (2008) and Blalock and Gertler (2008), in addition to intra-industry spillovers, there may be greater 
spillovers between industries through backward and forward linkages. To test potential inter-industry spillovers we add measures of outward FDI in a firm's upstream and downstream industries to equation (1) and the results are shown in column 2 of Table 2. The regression is shown below:

$$
\ln \text { TFP }_{i j t}=\alpha+\beta_{1} \text { Horizontal }_{j t}+\beta_{2} \text { Backward }_{j t}+\beta_{3} \text { Forward }_{j t}+\alpha_{j}+\alpha_{t}+\varepsilon_{i j t}
$$

Backward $_{j t}$ is a proxy for outward FDI in industries that are supplied by U.S. firms in industry j. It captures spillovers from U.S. multinational customers to their suppliers in the U.S. and, following Javorcik (2004), is defined as:

$$
\text { Backward }_{j t}=\sum_{k \text { if } k \neq j} \sigma_{j k} \text { Horizontal }_{k t}
$$

where $\alpha_{j k}$ is the proportion of industry $j$ 's production purchased by industry $k$ as intermediate inputs. To illustrate the vertical linkage represented by this variable, suppose that the steel industry sells 30 percent of its output to the machinery industry and the other 70 percent to the automobile industry. If U.S. affiliate sales of machinery abroad is 40 percent of the domestic sales of machinery in the U.S. and the U.S. affiliate sales of automobiles abroad is the same as the sales of automobiles in the U.S., then the Backward variable is calculated as: $0.3 * 0.4+0.7 * 1=0.82$. Such a variable captures outward FDI activities in an industry's downstream industries, weighted by the fraction of the industry's sales to each of the downstream industries.

$\alpha_{j k}$ is obtained from the 1999 input-output matrix published by the U.S. Bureau of Labor Statistics (BLS). ${ }^{6}$ A nice feature of using the BLS input-output matrix compared to that used in other studies of inter-industry spillovers is that the BLS input-output matrix is disaggregated at the 4-digit NAICS level which has approximately 200 sectors. If sectors are highly aggregated and the number of sectors is small, the supplier-customer relationship are mostly within sectors rather than between sectors, which represents only a small proportion of all possible vertical spillovers.

\footnotetext{
${ }^{6}$ Although there are annual input-output matrices available from the BLS, a static input-output matrix is chosen to separate the effect of changes in outward FDI and changes the U.S. industry structures on domestic firms' productivity. Regressions using vertical linkages constructed from dynamic input-output matrices are also carried out and the results are similar.
} 


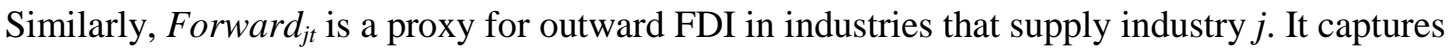
spillovers from U.S. multinational suppliers to their clients in the U.S. and is defined as:

$$
\text { Forward }_{j t}=\sum_{\mathrm{m} i f \mathrm{~m} \neq j} \sigma_{j m} \text { Horizontal }_{m t}
$$

where $\sigma_{j m}$ is the fraction of industry $j$ 's intermediate inputs supplied by industry $m . \sigma_{j m}$ is also obtained from the BLS input-output matrix. Forward $d_{j t}$ is a weighted average of outward FDI activities in an industry's upstream industries. All proxies for outward FDI are at the 4-digit NAICS industry level.

Equation (2) is also estimated using OLS accounting for possible heteroskedasticity.

Corresponding results are shown in the second column of Table 2. After adding in the measures of interindustry FDI proxies, the coefficient on horizontal FDI does not change much. The spillovers from MNC customers to home country suppliers are positive, which is consistent with theoretical assumptions of positive spillovers from FDI. However, the spillovers from MNC suppliers to home country customers are negative and significant.

The OLS regression results suffer from a few econometric issues. First, there may be firm specific factors unknown to the econometrician but known to the firms which affect their productivity. Following Javorcik (2004), we assume that the unobserved heterogeneity across firms is time constant and use time differencing of the regression equation to eliminate such fixed firm-specific factors. A set of industry and time dummies are also added to the differenced equation to control for unobserved industrial, time and regional effects. Second, there are still some time-variant variables that affect a firm’s productivity which are omitted in the differenced equation. To better isolate the effect of outward FDI, we include a set of control variables that are potential determinants of the growth of TFP. ${ }^{7}$ The additional control variables included in the regression are domestic demand for intermediate inputs calculated from the BLS input-output matrix and a measure of the degree of capital utilization in the industry. The former picks up domestic demand shocks to a firm and the latter may be part of the error that correlates with

\footnotetext{
${ }^{7}$ Note that after time differencing, the dependent variable is $\ln \frac{\text { TFPijst }}{\text { TFPijst-1 }}$ which represents the growth rate of TFP.
} 
outward FDI. We also include a firm's market share and its markup in the control variables. A firm's market share in its industry and its markup pick up the degree of competition faced by that firm. The higher its market share and markup, the less competitive pressure a firm faces and, as a result, it has less incentive to improve its production technology. Therefore, the sign on the estimated coefficient on firm market share and markup on productivity are both expected to be negative. Finally, in the standard OLS regression the standard errors of the estimates will be downward biased if the error terms are correlated within groups in some way, which leads to spurious statistical significance of the estimated coefficients. To deal with potential correlations of the errors, we allow errors belonging to the same 3-digit NAICS industries to be correlated.

\section{$4 \quad$ Model in Differences}

\subsection{Baseline Regression}

After all the econometric improvements made to the OLS specification in equation (2), the following differenced equation is estimated with clustered standard errors:

$$
\begin{aligned}
\Delta \ln \text { TFP }_{i j t}= & \alpha+\beta_{1} \Delta \text { Horizontal }_{j t}+\beta_{2} \Delta \text { Backward }_{j t}+\beta_{3} \Delta \text { Forward }_{j t} \\
& +\theta_{1} \text { fm }_{i j t-1}+\theta_{2} \text { ms }_{i j t-1}+\theta_{3} d_{j t-1}+\theta_{4} c u_{j t-1}+\alpha_{j}+\alpha_{t}+\varepsilon_{i j t}
\end{aligned}
$$

where $m s$ and $f m$ are market share and firm markup. $l d$ and $c u$ are the log of intermediates demand and the degree of capital utilization. $\alpha_{j}$ and $\alpha_{t}$ are industry and year dummies. Descriptive statistics of all the variables are provided in Table 3.

Results from the differenced regression are shown in Table 4. The first column shows the result when only horizontal FDI spillovers are considered. After controlling for unobserved heterogeneity across firms and other variables that affect TFP, the coefficient on horizontal FDI becomes negative and statistically insignificant. Similar to Kathuria (2000) and Javorcik (2004), no evidence of general intraindustry spillovers is found, which is consistent with the hypothesis that multinationals tend to prevent their advanced technologies from leaking to their competitors so as to protect their own market power. 
All of the other explanatory variables are statistically significant. The coefficients on market share and firm markup which measure the competitive pressure a firm faces are negative, indicating that greater competitive pressures lead to faster growth. The degree of capital utilization is positively correlated with TFP while demand for intermediate goods is negatively correlated with TFP.

The second column in Table 4 shows the results that add FDI spillovers from vertical linkages. The coefficient on backward FDI suggests that there is still evidence of spillovers from MNCs to their suppliers. Although the magnitude of the coefficient is smaller and the estimate is less significant, the coefficient is economically meaningful. A one-standard deviation increase of outward FDI activities carried out by a firm's MNC customers (that is, an increase of 0.18 in the backward variable) is associated with a 2.8 percent increase in its TFP. The coefficient on forward FDI is still negative but not statistically significant.

Comparing the results in the first two columns of Table 4 with the results in Table 2, we see the importance of controlling for firm-specific effects when evaluating FDI spillovers. The estimated coefficients from the OLS regression might be biased and their significance might be spurious. After correcting for such problems, no spillover is found from outward FDI in the same industry and in upstream industries. The significant and economically meaningful backward productivity spillovers from MNCs to their home country suppliers are consistent with many of the recent studies on host country spillovers (Javorcik 2004, Liu 2008, and Blalock and Gertler 2008).

To test whether it takes time for spillovers to be realized for domestic firms, in column 3 of Table 4 we use lagged FDI proxies instead of the contemporaneous ones. The signs of all the lagged FDI proxies become negative and none of the coefficients are statistically significant, which suggests that the spillovers occur rather quickly to receiving firms. In the last column of Table 4, a specification with twoyear differences is used to further reduce the noise in the regression at the expense of losing a large number of observations. ${ }^{8}$ Now the coefficient on horizontal FDI becomes positive, although still not

\footnotetext{
${ }^{8}$ Using two-year differences in column 4 of Table 4 reduces the number of firms in the regression from 654 in column 2 to 504 . We also regress the equation in column 2 with the 504 firms and the results are similar to the
} 
significant. The coefficients on backward FDI remain positive and become greater in magnitude and statistically more significant. This result again shows that spillovers from U.S. MNCs to their U.S. suppliers are more prevalent than spillovers to competing U.S. firms. The coefficient on forward spillovers becomes significant at the 10 percent level. The negative sign indicates that U.S. outward FDI might hurt firms that are supplied by U.S. multinationals.

\subsection{Robustness Check}

\subsubsection{Alternative Measure of Total Factor Productivity}

The Olley-Pakes method of estimating TFP requires some assumptions to produce consistent estimates. If there are substantial adjustment costs to investment, the investment function may have kink points and plants may not respond fully to $\omega_{i t}$. As a result, the correlation between inputs and the error terms still exists. The Olley-Pakes approach also needs plants to report non-zero investment for TFP estimation. Levinsohn and Petrin (2003) propose using intermediate inputs such as materials, electricity or fuels which are less costly to adjust as proxies for unobserved productivity shocks. In this section, we will first discuss how to estimate TFP using the Levinsohn-Petrin method and then test outward FDI spillovers on TFP estimated from this approach.

The Levinsohn-Petrin approach assumes that the intermediate input $m_{i t}$ is a function of state variables $k_{i t}$ and $\omega_{i t}$. Under some mild assumptions, this function can be inverted so that $\omega_{i t}=\omega_{t}\left(k_{i t}, m_{i t}\right)$. The estimation of labor and capital elasticities takes two steps. The first step is to estimate the following equation:

$$
y_{i t}=\alpha_{0}+\alpha_{l} l_{i t}+\phi\left(k_{i t}, m_{i t}\right)+\eta_{i t}
$$

where $\phi\left(k_{i t}, m_{i t}\right)=\alpha_{0}+\alpha_{k} k_{i t}+\omega_{t}\left(k_{i t}, m_{i t}\right) . \omega_{t}\left(k_{i t}, m_{i t}\right)$ is approximated by a third-order polynomial in $k_{i t}$ and $m_{i t}$. From the first step, a consistent estimate of $\alpha_{l}$ is obtained.

In the second step, the estimate of $\alpha_{k}$ can be obtained from solving

results in column 2 . The firms dropped from the sample because of taking longer difference do not have a significant impact on the baseline regression results in column 2 . 


$$
\min _{\alpha_{k}^{*}} \sum_{t}\left(y_{i t}-\hat{\alpha}_{l} l_{i t}-\alpha_{k}^{*} k_{i t}-E\left[\omega_{i t} \mid \omega_{i, t-1}\right]\right)
$$

Assuming $\omega_{i t}$ follows a first-order Markov process $\omega_{i t}=E\left[\omega_{i t} \mid \omega_{i t-1}\right]+\xi_{i t}$, then $E\left[\widehat{\omega_{i t} \mid \widehat{\omega_{i t-1}}}\right]$ is a nonparametric approximation to $E\left[\omega_{i t} \mid \omega_{i t-1}\right]$ which is obtained from the predicted value of the regression below

$$
\hat{\omega}_{i t}=\gamma_{0}+\gamma_{1} \hat{\omega}_{i, t-1}+\gamma_{2} \hat{\omega}_{i, t-1}^{2}+\gamma_{3} \hat{\omega}_{i, t-1}^{3}+\varepsilon_{i t}
$$

where $\hat{\omega}_{i t}$ is computed as $\hat{\omega}_{i t}=\hat{y}_{i t}-\hat{\alpha}_{l} l_{i t}-\alpha_{k}^{*} k_{i t}$ for any candidate value $\alpha_{k}^{*}$.

Once the estimates of $\alpha_{l}$ and $\alpha_{k}$ are obtained, TFP can be calculated from the Cobb-Douglas production function. All regressions in Table 4 are implemented again using TFP estimated from the Levinsohn-Petrin method to check the robustness of the results. Corresponding results are shown in Table 5. As shown in the table, both the magnitudes and significance levels of all the coefficients are only slightly changed. Only positive spillovers from MNC customers to their home country suppliers are found in the differenced equation. The conclusion that in general backward FDI spillovers on productivity are more likely to be realized is robust to TFP estimated from the Levinsohn-Petrin approach.

\subsubsection{Labor Productivity}

There is an active debate among economists regarding the appropriateness of using TFP to measure productivity. Some argue that TFP depends too heavily on arbitrary assumptions and is only useful for analysis over the long run with reliable data on capital. Labor productivity, calculated as output per unit of labor, may be a better measure in the short run since it does not rely on any assumption in the underlying model of production (Sargent and Rodriguez 2001). As a robustness check, we replicated the regressions in table 4 using labor productivity of the companies as the dependent variable. Labor productivity is measured as sales per employee for each Compustat company following Abowd et al. (2005).

Table 6 demonstrates the regression results using labor productivity as the dependent variable. In 
the second column, both horizontal FDI and backward FDI show positive spillovers but only the coefficient on backward FDI is statistically significant. Forward FDI shows negative but insignificant spillovers. In the third column with lagged FDI measures, the positive spillovers from horizontal FDI and negative spillovers from forward FDI become significant. In summary, we find similar results of outward FDI spillovers on labor productivity. There are significant positive spillovers from backward FDI and weak evidence of spillovers from horizontal and forward FDI.

\section{Determinants of Spillovers}

\subsection{Absorptive Capacity}

The evidence of general spillovers shown in the previous sections is quite limited. It is possible, however, that individual firms' heterogeneity may affect the spillovers they receive. A key factor that might determine whether and how much a firm would receive is its absorptive capacity (AC) which is usually defined as the gap between its own productivity and the leading firm's productivity in its industry.

There are two contradicting views regarding how absorptive capacity affects a firm's ability to benefit from other MNCs’activities. On one hand, Findlay (1978) and Wang and Blomström (1992) argue that the more backward a firm's technological level, the greater potential opportunities for the firm to benefit from assimilated advanced technologies. According to this view, firms with the largest gap from the technological frontier are the most likely to receive positive spillovers. On the other hand, Glass and Saggi (2002) and Kinoshita (2001) suggest that technology diffusion is not automatic and firms need to possess a basic technological base to adopt advanced technology. In accordance with this view, firms near the technological frontier have greater capacities to make the best use of other firms’ technology.

Empirical studies on how absorptive capacity affects spillovers from FDI find evidence supporting both views (Griffith et al. 2002 and Castellani and Zanfei 2003 are consistent with the former and Girma et al. 2001 with the latter). We assume that the effect of a firm's technological gap is not necessarily monotone on the spillovers it obtains from MNCs. Firms with a large gap have greater potential for productivity growth and can assimilate less complex knowledge which gives them specific 
benefits. Firms that are already in advanced technological positions have little room for drastic improvement but can assimilate more complex knowledge as they have sufficient absorptive capabilities. If we allow the effect of absorptive capacity to be nonlinear on FDI spillovers, the two seemingly contradicting views can be combined into one specification as follows:

$$
\begin{aligned}
\Delta \ln \operatorname{TFP}_{i j t}= & \alpha+\left(\beta_{11}+\beta_{12} A C_{i j t}+\beta_{13} A C_{i j t}^{2}\right) \Delta \text { Horizontal }_{j t} \\
& +\left(\beta_{21}+\beta_{22} A C_{i j t}+\beta_{23} A C_{i j t}^{2}\right) \Delta \text { Backward }_{j t} \\
& +\left(\beta_{31}+\beta_{32} A C_{i j t}+\beta_{33} A C_{i j t}^{2}\right) \Delta \text { Forward }_{j t} \\
& +\theta_{1} \text { ms }_{i j t}+\theta_{2} \text { fm }_{i j t}+\theta_{3} l d_{j t}+\theta_{4} c u_{j t}+\theta_{5} A C_{i j t}+\alpha_{j}+\alpha_{t}+\varepsilon_{i j t}
\end{aligned}
$$

In the above equation, absorptive capacity $\left(A C_{i j t}\right)$ is defined as a firm's TFP at period t- 1 divided by the maximal TFP of the firm's industry at period t-1. A large value of $A C_{i j t}$ implies that a firm is near the technological frontier and vice versa. The effects of outward FDI depend on both the level and the square of the absorptive capacity of the U.S. firms. Such a nonlinear specification allows more flexibility in how a firm's absorptive capacity affects the spillovers it receives from MNCs.

The results of the regression with absorptive capacity are show in Table 7. The first column presents the result when only the AC variable is added to the regression. The negative and significant coefficient on AC is consistent with the catch-up effect — firms lagged further behind tend to grow more rapidly. Compared to the second column of Table 5, the coefficients on the other variables do not change much after including the AC variable. In the second column of Table 7, interactions of the AC and FDI variables are allowed. We first include the product of the AC variable and FDI presence to test whether spillover effects are affected linearly by the level of absorptive capacity. As shown in the table, none of the interaction terms with the three types of FDI is statistically significant.

The effect of absorptive capacity on FDI spillovers may be nonlinear. Firms at the two ends of the spectrum of productivity distributions have different ways of using external knowledge. Therefore in the third column of Table 7, both the level of the AC variable and its square are interacted with the FDI variables to allow a quadratic effect of the absorptive capacity on spillovers.

The coefficients on the interactions of the squared absorptive capacity and FDI are statistically 
significant at the 5 percent level for both horizontal and backward FDI, which confirms the nonlinear effect on spillovers. The signs of the coefficients are positive, implying a U-shape function of absorptive capacity. However, we find no evidence of significant spillovers from upstream FDI to home country suppliers even if we control for absorptive capacity of the firms.

The U-shape function found for horizontal and backward FDI combines the two views regarding absorptive capacity discussed above. For firms with a low level of technology, the further they are from the technological frontier the greater the benefits they receive from outward FDI in the same industry and downstream industries. This is probably because those firms have greater potential for growth and the external knowledge from MNCs is of greater value to those firms once assimilated. For firms with an advanced level of technology, the closer they are to the technological frontier the more spillovers they receive from outward FDI in the same industry and downstream industries. The reason for this type of firm to enjoy extra benefits is likely because they possess greater technology know-how which enables them to be more capable of making good use of the external knowledge from MNCs.

Figure 1 shows how the spillover effect depends on a firm's absorptive capacity using the estimated coefficients in column 3. ${ }^{9}$ Quantitatively, horizontal spillovers increase (decrease) with respect to a firm's absorptive capacity for firms with an absorptive capacity greater (less) than 0.223 . The intraindustry spillovers are also positive for firms with an absorptive capacity less than 0.058 (135 firms on average) and greater than 0.388 (88 firms on average), which accounts for more than 30 percent of the 654 firms in the sample. Backward spillovers increase (decrease) with respect to a firm's absorptive capacity for firms with an absorptive capacity greater (less) than 0.363 . The inter-industry spillovers are also positive for firms with an absorptive capacity less than 0.237 (444 firms) and greater than 0.489 (41 firms), which accounts for more than 70 percent of the firms in the sample.

Using the more flexible specification of absorptive capacity, we find a nonlinear effect of the absorptive capacity on the benefits firms receive from outward FDI. Such a nonlinear effect indicates that

\footnotetext{
${ }^{9}$ The two lines in Figure 1 are the point estimates of the spillovers from horizontal and vertical FDI as a function of firms' absorptive capacity. In the appendix, we also show the $95 \%$ confidence interval of the point estimates of the spillover effect.
} 
firms at the two extreme of the distribution of technology levels (either those near the technological frontier or those with a large technological gap) will enjoy the greatest benefits of outward FDI activities in the same industry or downstream industries.

\subsection{Exporters vs. Non-Exporters}

Another characteristic of home country firms that might affect the spillovers they receive is their exporting experience. Firms that are exporters have more knowledge of and experience with foreign markets, which may make them more capable of understanding and absorbing technologies related to foreign markets obtained by U.S. MNCs. In addition, firms that have exporting experience are also more likely to be chosen by MNCs as suppliers to their foreign affiliates and therefore have a better chance of receiving assistance from multinational customers. Compustat has a segment in which firms’ export sales are reported. We use this information to differentiate exporters and non-exporters. An exporting firm is defined as a firm which has at least one year of positive export sales during the sample period. Using this standard, there are 217 firms that are exporters and 432 firms that are non-exporters in the sample.

Table 8 shows the results when the sample is divided between the two types of firms. In column (1) and (3) the first differenced equation (3) is regressed for exporting and non-exporting firms, respectively. The coefficients on FDI are all positive for exporting firms and statistically significant on backward FDI. For non-exporting firms, the coefficients are negative on horizontal FDI and forward FDI. Only the coefficient on backward FDI is positive while not significant.

The differences between the first and third columns are consistent with the view that U.S. firms with exporting experience are more likely to receive positive spillovers from U.S. MNCs. Exporting firms in general receive benefits from outward FDI, especially from their MNC customers. Their experience in dealing with foreign customers and exposure to foreign competition enable them to better absorb and make use of the advanced technologies possessed by MNCs. On the other hand, firms that have not exported do not receive productivity gains from MNCs and may even be damaged from outward FDI.

Columns (2) and (4) in Table 8 show the difference between exporters and non-exporters when 
we account for absorptive capacity. In column (2), where spillover effects are allowed to depend on absorptive capacity, absorptive capacity has a nonlinear U-shape effect on horizontal spillovers. Although on average non-exporters do not receive positive spillovers in column (3), their absorptive capacities do have an impact on spillovers. The effects of absorptive capacity are significant and also U-shaped for horizontal and backward FDI, indicating that non-exporting firms that are lagged further behind or closer to the technological frontier are more likely to receive productivity spillovers. This again confirms the importance of taking firm heterogeneity into account when evaluating the spillover effect. In sum, exporting experience helps a firm to better absorb potential spillovers from MNCs, especially when they have MNCs as clients.

\subsection{Small Firms vs. Large Firms}

The size of a firm may also affect the likelihood of receiving positive spillovers. Aitken and Harrison (1999) find negative spillovers on small domestic plants in Venezuela but not on large plants and posit that this is because small plants cannot compete as effectively with foreign MNCs as large plants. However, Sinani and Meyer (2004) find small firms may enjoy more spillovers as they are less bureaucratic, making it easier to adjust to new technologies.

To test whether outward FDI affects equally the small and large U.S. firms we divide our sample into small and large firms according to the criterion of U.S. Small Business Administration (SBA). According to the SBA rule, firms with less than 500 employees are considered as small firms in most industries.

Equations (3) and (4) are regressed for small and large firms and results are shown in Table 9. From the first and third column we can see that only small-sized firms receive positive spillovers from outward FDI in downstream industries. When the absorptive capacity of the recipient firms is taken into account, a U-shape effect of absorptive capacity is found on horizontal and backward FDI for small firms. In general, all the results found in the mixed sample still hold on the sample of small firms. No general spillover effect is found for large firms. However, an interesting result is found for large firms when their 
absorptive capacity is interacted with FDI presence. The last column shows that absorptive capacity has a U-shape effect on forward spillovers but no effect on the other two spillovers for large firms. This suggests that small firms and large firms not only are affected differently by outward FDI but also receive different impacts of absorptive capacity on potential spillovers.

\section{Conclusion}

A number of researchers have tested for evidence of productivity spillovers from FDI to host country firms. In this paper we explore the other side of the issue by examining spillovers from U.S. MNCs to domestic firms in their home country, the United States. Using firm level data from the Compustat dataset, we calculate firms' TFP using the Olley-Pakes method which accounts for simultaneity of input choices and selection bias. A measure of U.S. outward FDI in a domestic U.S. firm’s own industry is constructed using data from the BEA to capture intra-industry spillovers. To further explore the possibility of inter-industry spillovers, FDI activities in a firm’s upstream and downstream industries are also constructed using the input-output matrix from the BLS.

Similar to evidence found in many studies of host country spillovers, no general benefit from FDI in the same industry and in upstream industries is found for home country firms. However, significant productivity spillovers are found to flow from multinational firms to their home country suppliers. This is also consistent with the host country spillover literature that positive spillovers are more likely to take place between domestic firms and their multinational clients since they are not competing with each other (which makes the MNCs less likely to prevent knowledge leakage). The magnitude of spillovers from FDI in downstream industries is also economically significant. A one-standard deviation increase of outward FDI activities is on average associated with a 2.8 percent increase in a home country firm's TFP.

We also find that a firm's absorptive capacity, measured as the technological gap between a firm and the leading firm in its industry, plays a critical role in determining spillovers. Unlike most of the previous studies that assume a linear effect of absorptive capacity on spillover effects, we allow a nonlinear specification of the dependence of spillovers on absorptive capacity and find a U-shaped effect of 
absorptive capacity on horizontal and backward spillovers. Such nonlinearity indicates that firms with either low levels or high levels of productivity are more likely than other firms to enjoy positive spillovers. This is likely because firms with low levels of productivity have greater potential for productivity growth and firms with high levels of productivity are more capable of adopting the complex technologies possessed by MNCs.

Besides absorptive capacity, there are two other characteristics of the recipient U.S. firms that affect the spillovers they obtain. In general, exporting and small firms are more likely to receive positive spillovers from outward FDI in downstream industries. The effect of absorptive capacity on spillovers also depends on the exporting status and size of the recipient domestic firms.

Opponents of outward FDI argue that MNCs export domestic jobs to foreign countries, shift productive capital abroad and generate no benefit to the home country. The findings in this paper imply that there are productivity spillovers from outward FDI to domestic firms, especially to domestic suppliers of home country MNCs, and support the implementation of policies that subsidize outward FDI. The results also suggest that absorptive capacity plays a critical role in explaining the extent (if any) of productivity spillovers to recipient firms.

There are a number of extensions that could be made to this study. As suggested in the host country spillover literature, spillovers from MNCs not only affect firms’ productivity but also other factors such as employment and exporting decisions. Future studies on home country spillovers can further investigate spillovers in other aspects of the receiving firms. Other than characteristics of home country firms, the characteristics of MNCs engaging in FDI may also be critical to the realization of spillovers. However, the outward FDI data from the BEA do not provide information that is detailed enough to explore this question. If more detailed data on the U.S. outward MNCs become available, it would be interesting to examine what type of FDI is more likely to induce spillovers to home countries. In addition, the few existing studies on outward FDI spillovers have used data from developed countries partly because the majority stock of outward FDI in the world comes from wealthy nations. But some developing economies such as China are becoming important sources of outward FDI. Future work could 
examine the home country spillover effects of FDI for developing countries. 


\section{References}

Abowd, J.M., Haltiwanger, J., Jarmin, R., Lane, J., Lengermann, P., McCue, K., McKinney, K. and K. Sandusky (2005). The relation among human capital, productivity, and market value: Building up from micro evidence. In Measuring capital in the new economy (pp. 153-204). University of Chicago Press.

Aitken, B., and A. Harrison. (1999). Do domestic firms benefit from direct foreign investment? Evidence from Venezuela. American Economic Review, 89(3): 605-618.

Almeida, P. (1996). Knowledge sourcing by foreign multinationals: patent citation analysis in the US semiconductor industry. Strategic Management Journal 17: 155-165.

Arnold, J.M., and K. Hussinger. (2010). Exports versus FDI in German manufacturing: firm performance and participation in international markets. Review of International Economics, 18(4): 595-606.

Barrios, S., and E. Strobl. (2002). Foreign direct investment and productivity spillovers: Evidence from the Spanish experience. Review of World Economics, 138(3): 459-481.

Barba Navaretti, G., D. Castellani and A.-C. Disdier. (2010). 'How Does Investing in Cheap Labour Countries Affect Performance at Home? Firm-level Evidence from France and Italy’, Oxford Economic Papers, 62(2), 234-60.

Bartelsman, E., and W. Gray. (2001). NBER Productivity Database. www.nber.org.

Becker, S. O. and M.-A. Muendler. (2008). 'The Effect of FDI on Job Security', The B.E.Journal of Economic Analysis \& Policy, 8(1), Article 8.

Blalock, G., and P. Gertler. Welfare gains from foreign direct investment through technology transfer to local suppliers. Journal of International Economics, 74(2): 402-421.

Braconier, H., Ekholm, K. and K. Knarvik. (2001). In search of FDI-transmitted R\&D spillovers: A study based on Swedish data. Review of World Economics, 137(4): 644-665.

Castellani, D., and A. Zanfei. (2003). Technology gaps, absorptive capacity and the impact of inward investments on productivity of European firms. Economics of Innovation and New Technology, 12(6): 555-576.

Castellani, D., and A. Zanfei. (2006). Attracting foreign investments or promoting domestic multinationals? Evidence from productivity spillovers in Italy. Working paper.

Caves, R. (1974). Multinational firms, competition, and productivity in host-country markets. Economica, 41(162): 176-193.

Chung, W. and J. Alcácer (2002). Knowledge seeking and location choice of foreign direct investment in the United States. Management Science 48(12): 1534-1554. 
Das, S. (1987). Externalities, and technology transfer through multinational corporations A theoretical analysis. Journal of International Economics, 22(1-2): 171-182.

Desai, M., Foley, C. and J. Hines. (2009). Domestic Effects of the Foreign Activities of US Multinationals. American Economic Journal: Economic Policy, 1(1): 181-203.

Driffield, N., Love, J., and K. Taylor. (2009). Productivity and Labour Demand Effects of Inward and Outward FDI on UK Industry. The Manchester School, 77(2), 171-203, March.

Dunning, J., and R. Narula. (1995). The R\&D activities of foreign firms in the United States. International Studies of Management \& Organization, 25(1/2): 39-74.

Findlay, R. (1978). Relative Backwardness, Direct Foreign Investment, and the Transfer of Technology: A Simple Dynamic Model. The Quarterly Journal of Economics, 92(1): 1-16.

Fosfuri, A., and M. Motta. (1999). Multinationals without advantages. The Scandinavian Journal of Economics, 101(4): 617-630.

Fosfuri, A., Motta, M., and T. Rønde. (2001). Foreign direct investment and spillovers through workers' mobility. Journal of International Economics, 53(1): 205-222.

Girma, S. (2005). Absorptive Capacity and Productivity Spillovers from FDI: A Threshold Regression Analysis. Oxford Bulletin of Economics and Statistics, 67(3): 281-306.

Girma, S., and H. Görg. (2005). Foreign Direct Investment, Spillovers and Absorptive Capacity: Evidence from Quantile Regressions. Kiel Working Papers 1248, Kiel Institute for the World Economy.

Girma, S., Greenaway, D., and K. Wakelin. (2001). Who Benefits from Foreign Direct Investment in the UK? Scottish Journal of Political Economy, 48(2): 119-33.

Glass, A., and K. Saggi. (2002). Multinational firms and technology transfer. The Scandinavian Journal of Economics, 104(4): 495-513.

Globerman, S. (1979). Foreign direct investment and 'spillover' efficiency benefits in Canadian manufacturing industries. Canadian Journal of Economics, 12(1): 42-56.

Globerman, S., Kokko, A., and F. Sjöholm. (2000). International technology diffusion: evidence from Swedish patent data. Kyklos, 53(1): 17-38.

Globerman, S., and D. Shapiro. (2008). Outward FDI and the economic performance of emerging markets. In: Savant, K.P. (Ed.), The Rise of Transnational Corporations from Emerging Markets: Threat or Opportunity?, Cheltenham: Edward Elgar, 229-271.

Görg, H., and D. Greenaway. (2004). Much Ado about Nothing? Do Domestic Firms Really Benefit from 
Foreign Direct Investment? World Bank Research Observer, 19(2): 171-197.

Görg, H. and E. Strobel. (2001).Multinational Companies and Productivity Spillovers: A Meta-Analysis.” Economic Journal, 111(473):F723-39.

Griffith, R., Simpson, H., and S. Redding. (2002). Productivity convergence and foreign ownership at the establishment level. IFS Working Papers W02/22, Institute for Fiscal Studies.

Harrison, A. and M. McMillan. (2011). "Offshoring Jobs? Multinationals and U.S. Manufacturing Employment," The Review of Economics and Statistics, 93(3), 857-875.

Helpman, E., M.J. Melitz, and S.R. Yeaple. (2004). Export versus FDI with heterogeneous firms. American Economic Review, 94(1): 300-316.

Javorcik, B.S. (2004). Does Foreign Direct Investment Increase the Productivity of Domestic Firms? In Search of Spillovers Through Backward Linkages. American Economic Review, 94(3): 605-627.

Javorcik, B.S., and M. Spatareanu. (2008). To Share or Not to Share: Does Local Participation Matter for Spillovers from Foreign Direct Investment? Journal of Development Economics, 85(1-2): 194217.

Kathuria, V. (2000). Productivity spillovers from technology transfer to Indian manufacturing firms. Journal of International Development, 12(3): 343-369.

Keller, W., and S. Yeaple. (2009). Multinational enterprises, international trade, and productivity growth: firm-level evidence from the United States. The Review of Economics and Statistics, 91(4): 821831.

Kinoshita, Y. (2001). R\&D and Technology Spillovers through FDI: Innovation and Absorptive Capacity. CEPR Discussion Papers 2775, C.E.P.R. Discussion Papers.

Kokko, A. (2006). The Home Country Effects Of FDI In Developed Economies. EIJS Working Paper Series 225, The European Institute of Japanese Studies.

Kokko, A., Tansini, R., and M. Zejan. (1996). Local technological capability and productivity spillovers from FDI in the Uruguayan manufacturing sector. The Journal of Development Studies, 32(4): 602-611.

Kolasa, M. (2008). How does FDI inflow affect productivity of domestic firms? The role of horizontal and vertical spillovers, absorptive capacity and competition. The Journal of International Trade\& Economic Development, 17(1): 155-173.

Kugler, M. (2006). Spillovers from Foreign Direct Investment: Within or between Industries? Journal of Development Economics, 80(2):444 -77.

Levinsohn, J., and A. Petrin. (2003). Estimating Production Functions Using Inputs to Control for 
Unobservables. Review of Economic Studies, 70(2): 317-341.

Liu, Z. (2008). Foreign direct investment and technology spillovers: Theory and evidence. Journal of Development Economics, 85(1-2): 176-193.

Markusen, J.R., and A.J. Venables. (1999). Foreign direct investment as a catalyst for industrial development. European Economic Review, 43(2): 335-356.

Olley, S., and A. Pakes. (1996). The dynamics of productivity in the telecommunications equipment industry. Econometrica, 64(6): 1263-97.

Poole, J.P.. (2006). Multinational spillovers through worker turnover. University of California, San Diego, mimeo.

Rodriguez-Clare, A. (1996). Multinationals, Linkages, and Economic Development. American Economic Review, 86(4): 852-73.

Sargent, T.C., and Rodriguez, E. R. (2001). Labour or total factor productivity: Do we need to choose? Department of Finance, Economic and Fiscal Policy Branch.

Simpson, H. (2012). "How do Firms' Outward FDI Strategies Relate to their Activity at Home? Empirical Evidence for the UK," The World Economy, 35(3), 243-272.

Sinani, E., and K.E. Meyer. (2004). Spillovers of technology transfer from FDI: the case of Estonia. Journal of Comparative Economics, 32(3): 445-466.

Slaughter, Matthew J. (2012). American Companies and Global Supply Networks Driving U.S. Economic Growth and Jobs by Connecting with the World. Business Roundtable; United States Council for International business; United States Council Federation: 1-64.

Smeets, R. (2008). Collecting the pieces of the FDI knowledge spillovers puzzle. The World Bank Research Observer, 23(2): 107-138.

Vahter, P., and J. Masso. (2007). Home versus Host Country Effects of FDI: Searching for New Evidence of Productivity Spillovers. Applied Economics Quarterly (formerly: Konjunkturpolitik), 53(2): 165-196.

Wagner, J. (2011). Offshoring and firm performance: self-selection, effects on performance, or both? Review of World Economics, 147(2): 217-247.

Wagner, J. (2006). Exports, foreign direct investment, and productivity: Evidence from German firm level data. Applied Economics Letters, 13(6): 347-349.

Wang, J., and M. Blomström. (1992). Foreign investment and technology transfer: A simple model. European Economic Review, 36(1): 137-155. 
Table 1

Olley-Pakes TFP Equation Estimation

\begin{tabular}{lccc}
\hline \hline NAICS & 31 & 32 & 33 \\
\hline \multirow{2}{*}{ Labor } & $0.688 * * *$ & $0.664 * * *$ & $0.758 * * *$ \\
& $(0.0568)$ & $(0.0384)$ & $(0.0365)$ \\
Capital & $0.284^{* * *}$ & $0.299^{* * *}$ & $0.209 * * *$ \\
& $(0.0835)$ & $(0.0661)$ & $(0.0363)$ \\
Sum & 0.972 & 0.963 & 0.967 \\
Observations & 664 & 1,280 & 2,677 \\
\hline \multicolumn{4}{l}{ Standard errors in parentheses. ${ }^{* * *} \mathrm{p}<0.01,{ }^{* *} \mathrm{p}<0.05}$, \\
$* \mathrm{p}<0.1$.
\end{tabular}

Table 2

Regression in Levels

\begin{tabular}{lcc}
\hline \hline & $(1)$ & $(2)$ \\
& TFP & TFP \\
\hline Horizontal & $0.245^{* * *}$ & $0.264^{* * *}$ \\
& $(0.0532)$ & $(0.0554)$ \\
Backward & & $0.485^{* * *}$ \\
& & $(0.123)$ \\
Forward & & $-0.579 * * *$ \\
& & $(0.138)$ \\
Constant & $2.722^{* * *}$ & $2.758^{* * *}$ \\
& $(0.0387)$ & $(0.0513)$ \\
Observations & & \\
R-squared & 3,896 & 3,896 \\
\hline
\end{tabular}

All regressions include industry and year dummies.

Robust standard errors in parentheses. ${ }^{* * *} \mathrm{p}<0.01$, ** $\mathrm{p}<0.05, * \mathrm{p}<0.1$ 
Table 3

Descriptive Statistics

\begin{tabular}{lrrrr}
\hline \hline & \multicolumn{1}{c}{ Mean } & Std. Dev. & \multicolumn{1}{c}{ Min } & \multicolumn{1}{c}{ Max } \\
\hline TFP & 35.255 & 47.960 & 0.120 & 792.548 \\
Horizontal & 0.395 & 0.314 & 0.003 & 2.712 \\
Backward & 0.315 & 0.180 & 0.010 & 1.636 \\
Forward & 0.305 & 0.155 & 0.059 & 1.374 \\
Market Share & 0.023 & 0.061 & $9.08 \mathrm{e}-06$ & 0.719 \\
Firm Markup & 1.006 & 0.210 & -3.634 & 4.170 \\
Intermediates Demand & 8.919 & 1.517 & 4.958 & 11.626 \\
Capital Utilization & 177.447 & 210.219 & 12.035 & 1520.81 \\
\hline
\end{tabular}


Table 4

Regression in First Difference

\begin{tabular}{|c|c|c|c|c|}
\hline & $\begin{array}{c}(1) \\
\Delta \operatorname{lnTFP}\end{array}$ & $\begin{array}{c}(2) \\
\Delta \operatorname{lnTFP}\end{array}$ & $\begin{array}{c}(3) \\
\Delta \operatorname{lnTFP}\end{array}$ & $\begin{array}{c}(4) \\
\Delta^{2} \operatorname{lnTFP}\end{array}$ \\
\hline$\Delta$ Horizontal & $\begin{array}{l}-0.0394 \\
(0.110)\end{array}$ & $\begin{array}{l}-0.0517 \\
(0.0910)\end{array}$ & & $\begin{array}{c}0.163 \\
(0.137)\end{array}$ \\
\hline Lagged $\Delta$ Horizontal & & & $\begin{array}{c}-0.0913 \\
(0.169)\end{array}$ & \\
\hline$\Delta$ Backward & & $\begin{array}{c}0.155^{*} \\
(0.0853)\end{array}$ & & $\begin{array}{c}0.264 * * \\
(0.124)\end{array}$ \\
\hline Lagged $\Delta$ Backward & & & $\begin{array}{c}-0.0588 \\
(0.110)\end{array}$ & \\
\hline$\Delta$ Forward & & $\begin{array}{l}-0.194 \\
(0.286)\end{array}$ & & $\begin{array}{l}-0.547^{*} \\
(0.263)\end{array}$ \\
\hline Lagged $\Delta$ Forward & & & $\begin{array}{l}-0.460 \\
(0.270)\end{array}$ & \\
\hline Firm Markup & $\begin{array}{c}-0.359 * * * \\
(0.0968)\end{array}$ & $\begin{array}{c}-0.359 * * * \\
(0.0969)\end{array}$ & $\begin{array}{c}-0.489 * * * \\
(0.0777)\end{array}$ & $\begin{array}{l}-0.223 \\
(0.133)\end{array}$ \\
\hline Market Share & $\begin{array}{c}-0.363 * * * \\
(0.107)\end{array}$ & $\begin{array}{c}-0.359 * * * \\
(0.105)\end{array}$ & $\begin{array}{c}-0.432 * * \\
(0.158)\end{array}$ & $\begin{array}{c}-0.706^{* *} \\
(0.257)\end{array}$ \\
\hline Intermediates Demand & $\begin{array}{l}-0.0200^{*} \\
(0.00988)\end{array}$ & $\begin{array}{c}-0.0221^{* *} \\
(0.00830)\end{array}$ & $\begin{array}{l}-0.0124^{* *} \\
(0.00559)\end{array}$ & $\begin{array}{c}-0.0289 * * \\
(0.0125)\end{array}$ \\
\hline Capital Utilization & $\begin{array}{c}0.000230 * * * \\
(5.19 \mathrm{e}-05)\end{array}$ & $\begin{array}{c}0.000230 * * * \\
(5.17 \mathrm{e}-05)\end{array}$ & $\begin{array}{c}0.000125^{* *} \\
(5.22 \mathrm{e}-05)\end{array}$ & $\begin{array}{c}0.000347^{* * *} \\
(0.000108)\end{array}$ \\
\hline Constant & $\begin{array}{c}0.480^{* * *} \\
(0.159)\end{array}$ & $\begin{array}{c}0.486 * * * \\
(0.143)\end{array}$ & $\begin{array}{c}0.604 * * * \\
(0.130)\end{array}$ & $\begin{array}{c}0.505^{* * *} \\
(0.150)\end{array}$ \\
\hline Observations & 2,740 & 2,740 & 2,342 & 1,229 \\
\hline R-squared & 0.048 & 0.049 & 0.057 & 0.077 \\
\hline
\end{tabular}


Table 5

Regression with TFP Estimation from the Levinsohn-Petrin Method

\begin{tabular}{|c|c|c|c|c|}
\hline & $\begin{array}{c}(1) \\
\Delta \operatorname{lnTFP}\end{array}$ & $\begin{array}{c}(2) \\
\Delta \operatorname{lnTFP}\end{array}$ & $\begin{array}{c}(3) \\
\Delta \operatorname{lnTFP}\end{array}$ & $\Delta^{2} \ln (4)$ \\
\hline$\overline{\Delta \text { Horizontal }}$ & $\begin{array}{l}-0.0416 \\
(0.110)\end{array}$ & $\begin{array}{c}-0.0520 \\
(0.0911)\end{array}$ & & $\begin{array}{c}0.166 \\
(0.136)\end{array}$ \\
\hline Lagged $\Delta$ Horizontal & & & $\begin{array}{l}-0.0877 \\
(0.173)\end{array}$ & \\
\hline$\Delta$ Backward & & $\begin{array}{c}0.158^{*} \\
(0.0857)\end{array}$ & & $\begin{array}{l}0.261^{*} \\
(0.131)\end{array}$ \\
\hline Lagged $\Delta$ Backward & & & $\begin{array}{l}-0.0637 \\
(0.111)\end{array}$ & \\
\hline$\Delta$ Forward & & $\begin{array}{l}-0.173 \\
(0.284)\end{array}$ & & $\begin{array}{l}-0.544^{*} \\
(0.264)\end{array}$ \\
\hline Lagged $\Delta$ Forward & & & $\begin{array}{l}-0.488^{*} \\
(0.263)\end{array}$ & \\
\hline Firm Markup & $\begin{array}{c}-0.354 * * * \\
(0.0971)\end{array}$ & $\begin{array}{c}-0.354 * * * \\
(0.0973)\end{array}$ & $\begin{array}{c}-0.488 * * * \\
(0.0786)\end{array}$ & $\begin{array}{l}-0.210 \\
(0.136)\end{array}$ \\
\hline Market Share & $\begin{array}{c}-0.383^{* * * *} \\
(0.110)\end{array}$ & $\begin{array}{c}-0.380 * * * \\
(0.108)\end{array}$ & $\begin{array}{c}-0.451 * * \\
(0.162)\end{array}$ & $\begin{array}{c}-0.749 * * * \\
(0.257)\end{array}$ \\
\hline Intermediates Demand & $\begin{array}{l}-0.0206 * \\
(0.0101)\end{array}$ & $\begin{array}{l}-0.0228 * * \\
(0.00862)\end{array}$ & $\begin{array}{l}-0.0128 * * \\
(0.00595)\end{array}$ & $\begin{array}{c}-0.0299 * * \\
(0.0134)\end{array}$ \\
\hline Capital Utilization & $\begin{array}{c}0.000228 * * * \\
(5.02 \mathrm{e}-05)\end{array}$ & $\begin{array}{c}0.000229 * * * \\
(5.00 \mathrm{e}-05)\end{array}$ & $\begin{array}{c}0.000121^{* *} \\
(5.52 \mathrm{e}-05)\end{array}$ & $\begin{array}{c}0.000343^{* * *} \\
(0.000113)\end{array}$ \\
\hline Constant & $\begin{array}{c}0.485^{* * *} \\
(0.160)\end{array}$ & $\begin{array}{c}0.489 * * * \\
(0.145)\end{array}$ & $\begin{array}{c}0.605^{* * *} * \\
(0.134)\end{array}$ & $\begin{array}{c}0.508 * * * \\
(0.154)\end{array}$ \\
\hline Observations & 2,740 & 2,740 & 2,342 & 1,229 \\
\hline R-squared & 0.049 & 0.050 & 0.058 & 0.080 \\
\hline
\end{tabular}

All regressions include industry and year dummies. Standard errors clustered at 3 -digit NAICS industry levels are in parentheses. ${ }^{* * *} \mathrm{p}<0.01,{ }^{* *} \mathrm{p}<0.05$,

$* \mathrm{p}<0.1$. 
Table 6

Regression with Labor Productivity as the Dependent Variable

\begin{tabular}{|c|c|c|c|c|}
\hline & $\begin{array}{c}(1) \\
\Delta \text { Labor } \\
\text { Productivity }\end{array}$ & $\begin{array}{c}(2) \\
\Delta \text { Labor } \\
\text { Productivity }\end{array}$ & $\begin{array}{c}(3) \\
\Delta \text { Labor } \\
\text { Productivity }\end{array}$ & $\begin{array}{c}\Delta^{2}(4) \\
\Delta^{2} \text { Labor } \\
\text { Productivity }\end{array}$ \\
\hline$\Delta$ Horizontal & $\begin{array}{c}99.01 \\
(94.48)\end{array}$ & $\begin{array}{c}88.64 \\
(90.11)\end{array}$ & & $\begin{array}{l}-0.923 \\
(38.23)\end{array}$ \\
\hline Lagged $\Delta$ Horizontal & & & $\begin{array}{c}59.41 * * \\
(27.95)\end{array}$ & \\
\hline$\Delta$ Backward & & $\begin{array}{c}37.20^{* *} \\
(13.86)\end{array}$ & & $\begin{array}{c}24.93 \\
(88.99)\end{array}$ \\
\hline Lagged $\Delta$ Backward & & & $\begin{array}{c}22.72 \\
(27.51)\end{array}$ & \\
\hline$\Delta$ Forward & & $\begin{array}{c}-135.5 \\
(96.21)\end{array}$ & & $\begin{array}{c}-502.5 * * \\
(199.8)\end{array}$ \\
\hline Lagged $\Delta$ Forward & & & $\begin{array}{l}-121.8^{*} \\
(57.75)\end{array}$ & \\
\hline Firm Markup & $\begin{array}{c}-25.55 * * * \\
(6.558)\end{array}$ & $\begin{array}{c}-25.25 * * * \\
(6.165)\end{array}$ & $\begin{array}{c}-45.08 * * * \\
(10.88)\end{array}$ & $\begin{array}{c}-13.03 \\
(25.94)\end{array}$ \\
\hline Market Share & $\begin{array}{c}-109.3 \\
(79.72)\end{array}$ & $\begin{array}{c}-108.4 \\
(79.03)\end{array}$ & $\begin{array}{l}-141.8 \\
(91.94)\end{array}$ & $\begin{array}{l}-15.07 \\
(85.31)\end{array}$ \\
\hline Intermediates Demand & $\begin{array}{c}3.926 \\
(2.660)\end{array}$ & $\begin{array}{c}3.110 \\
(2.196)\end{array}$ & $\begin{array}{c}3.477 \\
(3.265)\end{array}$ & $\begin{array}{c}1.591 \\
(4.634)\end{array}$ \\
\hline Capital Utilization & $\begin{array}{c}0.178 * * * \\
(0.0533)\end{array}$ & $\begin{array}{c}0.177 * * * \\
(0.0534)\end{array}$ & $\begin{array}{l}0.142^{* *} \\
(0.0517)\end{array}$ & $\begin{array}{c}0.285 * * * \\
(0.0441)\end{array}$ \\
\hline Constant & $\begin{array}{l}-21.08 \\
(33.26)\end{array}$ & $\begin{array}{c}-14.77 \\
(28.05)\end{array}$ & $\begin{array}{c}-21.23 \\
(36.91)\end{array}$ & $\begin{array}{l}-5.054 \\
(83.96)\end{array}$ \\
\hline Observations & 2,740 & 2,740 & 2,342 & 1,229 \\
\hline R-squared & 0.054 & 0.055 & 0.045 & 0.130 \\
\hline
\end{tabular}

All regressions include industry and year dummies. Standard errors clustered at 3-digit NAICS industry levels are in parentheses. ${ }^{* * *} \mathrm{p}<0.01,{ }^{* *} \mathrm{p}<0.05$,

$* \mathrm{p}<0.1$. 
Table 7

FDI Spillovers with Absorptive Capacity

\begin{tabular}{|c|c|c|c|}
\hline & $\begin{array}{c}(1) \\
\Delta \operatorname{lnTFP}\end{array}$ & $\begin{array}{c}(2) \\
\Delta \operatorname{lnTFP}\end{array}$ & $\begin{array}{c}(3) \\
\Delta \operatorname{lnTFP}\end{array}$ \\
\hline Absorptive Capacity & $\begin{array}{c}-0.722 * * * \\
(0.130)\end{array}$ & $\begin{array}{c}-0.729 * * * \\
(0.130)\end{array}$ & $\begin{array}{c}-0.794 * * * \\
(0.116)\end{array}$ \\
\hline$\Delta$ Horizontal & $\begin{array}{l}-0.00467 \\
(0.0772)\end{array}$ & $\begin{array}{l}-0.125 \\
(0.233)\end{array}$ & $\begin{array}{c}0.283 \\
(0.204)\end{array}$ \\
\hline$\Delta$ Horizontal*Absorptive Capacity & & $\begin{array}{l}1.026 \\
(1.601)\end{array}$ & $\begin{array}{l}-5.603^{*} \\
(2.909)\end{array}$ \\
\hline$\Delta$ Horizontal*Absorptive Capacity $^{2}$ & & & $\begin{array}{l}12.57^{* *} \\
(5.582)\end{array}$ \\
\hline$\Delta$ Backward & $\begin{array}{l}0.180^{* *} \\
(0.0826)\end{array}$ & $\begin{array}{c}0.314^{* * *} \\
(0.108)\end{array}$ & $\begin{array}{c}0.542 * * * \\
(0.174)\end{array}$ \\
\hline$\Delta$ Backward*Absorptive Capacity & & $\begin{array}{l}-0.700 \\
(0.403)\end{array}$ & $\begin{array}{c}-3.393^{* *} \\
(1.264)\end{array}$ \\
\hline$\Delta$ Backward*Absorptive Capacity $^{2}$ & & & $\begin{array}{l}4.673^{* *} \\
(1.961)\end{array}$ \\
\hline$\Delta$ Forward & $\begin{array}{l}-0.215 \\
(0.277)\end{array}$ & $\begin{array}{l}-0.274 \\
(0.276)\end{array}$ & $\begin{array}{l}-0.0361 \\
(0.344)\end{array}$ \\
\hline$\Delta$ Forward*Absorptive Capacity & & $\begin{array}{l}0.0490 \\
(0.887)\end{array}$ & $\begin{array}{l}-3.231 \\
(2.640)\end{array}$ \\
\hline$\Delta$ Forward*Absorptive Capacity $^{2}$ & & & $\begin{array}{c}6.927 \\
(6.036)\end{array}$ \\
\hline Firm Markup & $\begin{array}{c}-0.271 * * * \\
(0.0637)\end{array}$ & $\begin{array}{c}-0.272 * * * \\
(0.0651)\end{array}$ & $\begin{array}{c}-0.259 * * * \\
(0.0651)\end{array}$ \\
\hline Market Share & $\begin{array}{l}-0.199 \\
(0.148)\end{array}$ & $\begin{array}{l}-0.192 \\
(0.149)\end{array}$ & $\begin{array}{l}-0.185 \\
(0.177)\end{array}$ \\
\hline Intermediates Demand & $\begin{array}{l}-0.0205^{*} \\
(0.0111)\end{array}$ & $\begin{array}{l}-0.0212^{*} \\
(0.0116)\end{array}$ & $\begin{array}{l}-0.0194 \\
(0.0124)\end{array}$ \\
\hline Capital Utilization & $\begin{array}{c}0.000330 * * * \\
(8.44 \mathrm{e}-05)\end{array}$ & $\begin{array}{c}0.000332^{* * * *} \\
(8.39 \mathrm{e}-05)\end{array}$ & $\begin{array}{c}0.000376^{* * *} \\
(0.000102)\end{array}$ \\
\hline Constant & $\begin{array}{c}0.458 * * * \\
(0.133)\end{array}$ & $\begin{array}{c}0.465 * * * \\
(0.141)\end{array}$ & $\begin{array}{c}0.429 * * \\
(0.153)\end{array}$ \\
\hline Observations & 2,740 & 2,740 & 2,740 \\
\hline R-squared & 0.072 & 0.073 & 0.079 \\
\hline
\end{tabular}

All regressions include industry and year dummies. Standard errors clustered at 3-digit NAICS industry levels are in parentheses. ${ }^{* * *} \mathrm{p}<0.01,{ }^{* *} \mathrm{p}<0.05,{ }^{*} \mathrm{p}<0.1$ 
Table 8

FDI Spillovers for Exporters and Non-Exporters

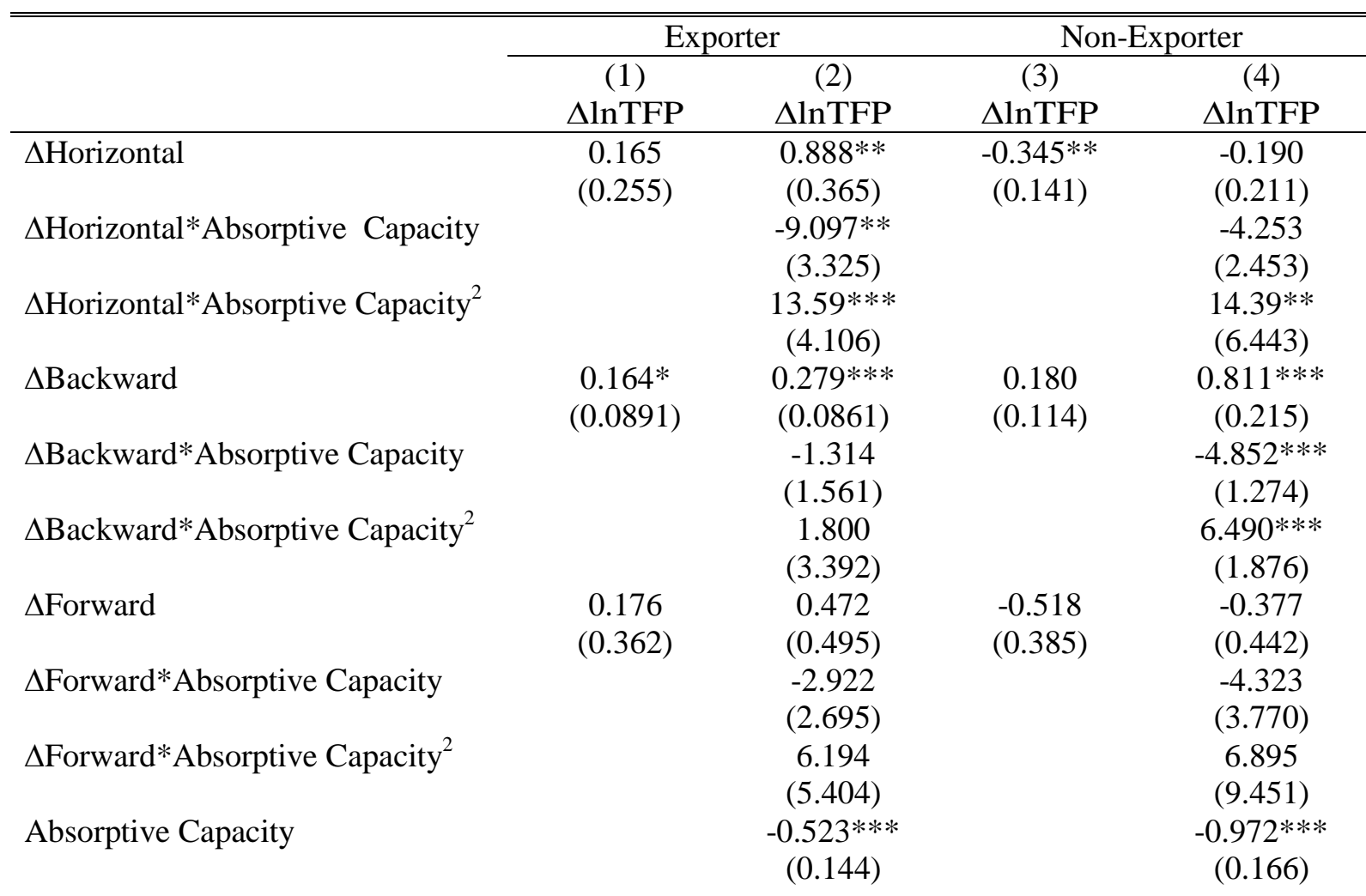

Firm Markup

$\begin{array}{cccc}-0.378^{* * *} & -0.297 * * * & -0.354^{* *} & -0.248^{* *} \\ (0.0497) & (0.0405) & (0.128) & (0.0956) \\ -0.0733 & -0.0313 & -0.365^{* * *} & -0.120 \\ (0.272) & (0.452) & (0.103) & (0.198) \\ -0.00742 & -0.00218 & -0.0331^{* * *} & -0.0312^{* *} \\ (0.00468) & (0.00672) & (0.00875) & (0.0141) \\ 0.000150^{* *} & 0.000326^{*} & 0.000283^{* * *} & 0.000409^{* * *} \\ (6.70 \mathrm{e}-05) & (0.000167) & (7.11 \mathrm{e}-05) & (9.14 \mathrm{e}-05) \\ 0.248^{* *} & 0.148 & 0.601^{* * *} & 0.578^{* * *} \\ (0.0902) & (0.0865) & (0.143) & (0.159) \\ 995 & 995 & 1,745 & 1,745 \\ 0.055 & 0.076 & 0.054 & 0.096\end{array}$

Observations

0.055

All regressions include industry and year dummies. Standard errors clustered at 3-digit NAICS industry levels are in parentheses. ${ }^{* * *} \mathrm{p}<0.01,{ }^{* *} \mathrm{p}<0.05,{ }^{*} \mathrm{p}<0.1$ 
Table 9

FDI Spillovers for Small and Large Firms

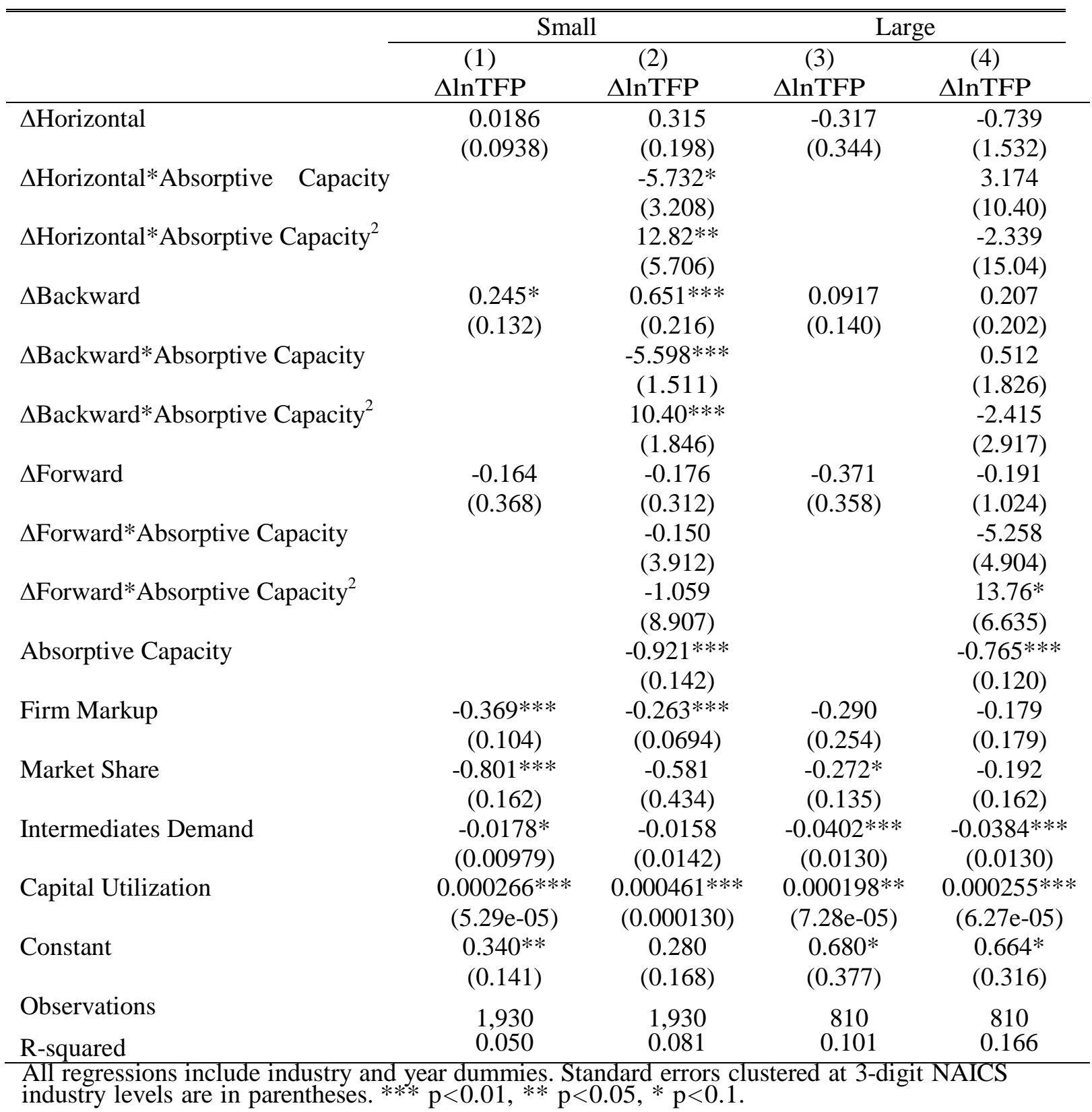


Figure 1

The Effects of Absorptive Capacity on FDI Spillovers

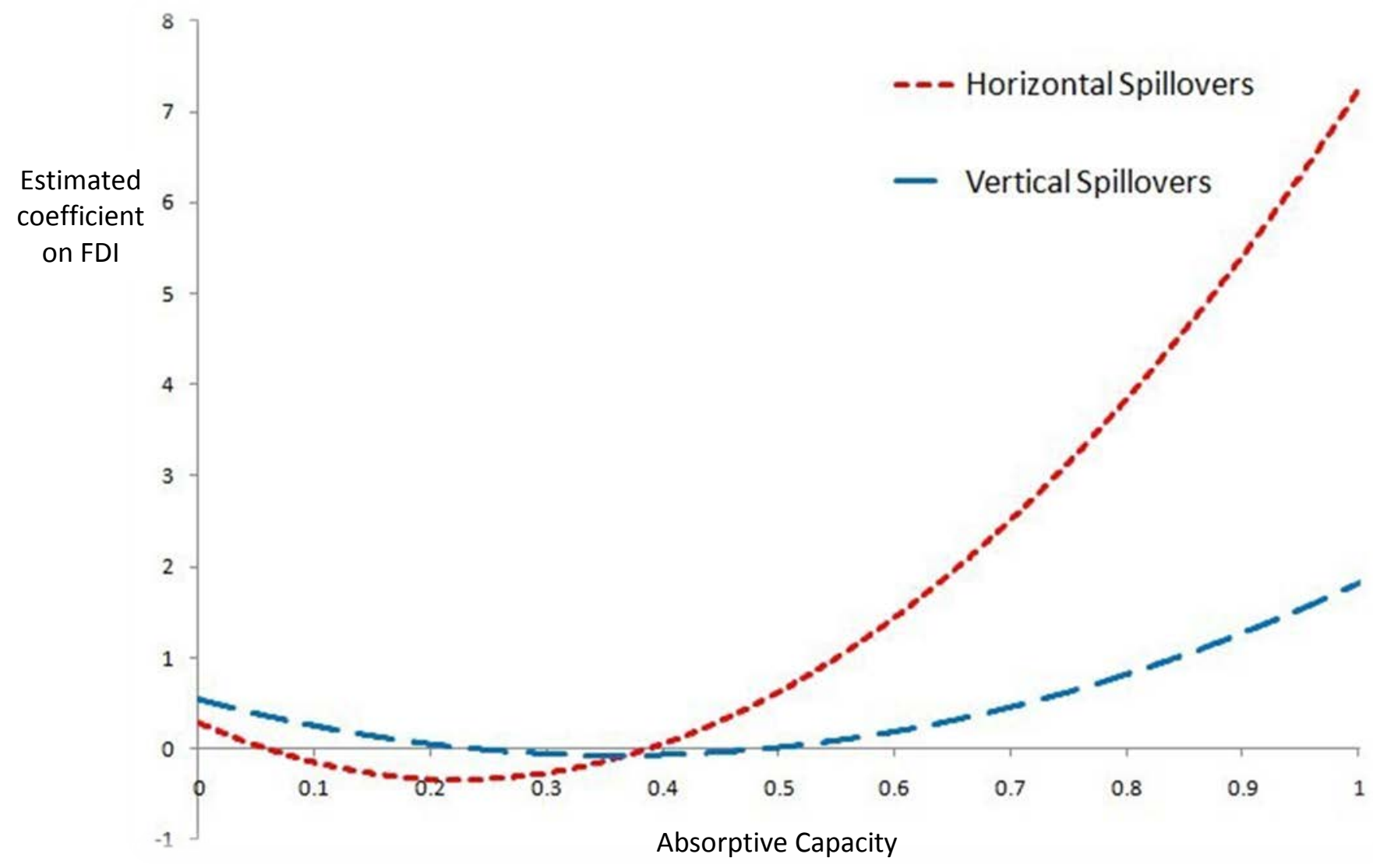

The figure shows how the spillover effect depends on a firm's absorptive capacity using the estimated coefficients in column 3 of Table 7. Vertical spillovers refer to backward spillovers. 


\section{Appendix}

\section{Variable Definition, Sources and Data Construction}

- Value Added $\left(y_{i t}\right)$ : Net sales from Compustat minus materials; deflators are from Bartelsman and Gray (2001). Unit: million.

- Labor $\left(l_{i t}\right)$ : Number of employees, from Compustat. Unit: thousand.

- Capital $\left(k_{i t}\right)$ : Value of property, plant, and equipment, net of depreciation, from Compustat; deflators are from the BEA fixed asset and chain-type quantity index. Unit: million.

- Material $\left(m_{i t}\right)$ : Cost of goods sold from Compustat plus administrative and selling expenses from Compustat minus depreciation from Compustat and labor expenses. Labor expenses are measured as labor multiplied by average wage of production workers from Bartelsman and Gray (2001); deflators are from Bartelsman and Gray (2001). Unit: million.

- Investment $\left(\mathrm{i}_{i t}\right)$ : Capital expenditure, from Compustat; deflators are from Bartelsman and Gray (2001). Unit: million.

- Age $\left(a_{i t}\right)$ : A firm's birth year is approximated as the earliest of: (a) the year in which the firm is first listed on CRSP; (b) the year in which the firm is first listed on Compustat; (c) the year in which there is a link between CRSP and Compustat. Then a firm's age is defined as the difference between its birth year and the year when the firm is observed (plus one to avoid zero age).

- Exit Dummy: Compustat reports the reason for and date on which a company is deleted from the database. An exit dummy is equal to 1 if a firm is deleted because of acquisition and merger, bankruptcy or liquidation.

- Market Share $\left(m s_{i t}\right)$ : The ratio of net sales from Compustat to industry sales from Bartelsman and Gray (2001).

- Firm Markup $\left(f m_{i t}\right)$ : The ratio of net sales over net sales minus profits. Profits are approximated by net income from Compustat.

- Capital Utilization $\left(c u_{i t}\right)$ : The ratio of capital stock over the total production workers' hours at 6-digit NAICS industry level, from Bartelsman and Gray (2001).

- Intermediate Demand $\left(i d_{\mathrm{jt}}\right): i d_{j t}=\sum_{k} \alpha_{j k} * Y_{k t}$ where $\alpha_{j k}$ represents the unit of good $j$ needed to produce one unit of good $\mathrm{k}$ from the BLS input-output matrix. $Y_{k t}$ is industry $k$ 's output from the BLS input-output data at 4-digit NAICS industry level. Unit: million.

\section{The Standard Deviations of Horizontal and Vertical Spillovers as a Function of Absorptive Capacity}

The vertical lines in Appendix Figure 1 and Appendix Figure 2 show the 95\% confidence 
intervals of the point estimates of the horizontal and vertical spillover effect at their percentiles. Firms distributed at the two ends of the spectrum of absorptive capacity tend to receive positive spillovers. 
Appendix Figure 1

The Effects of Absorptive Capacity on Horizontal Spillovers

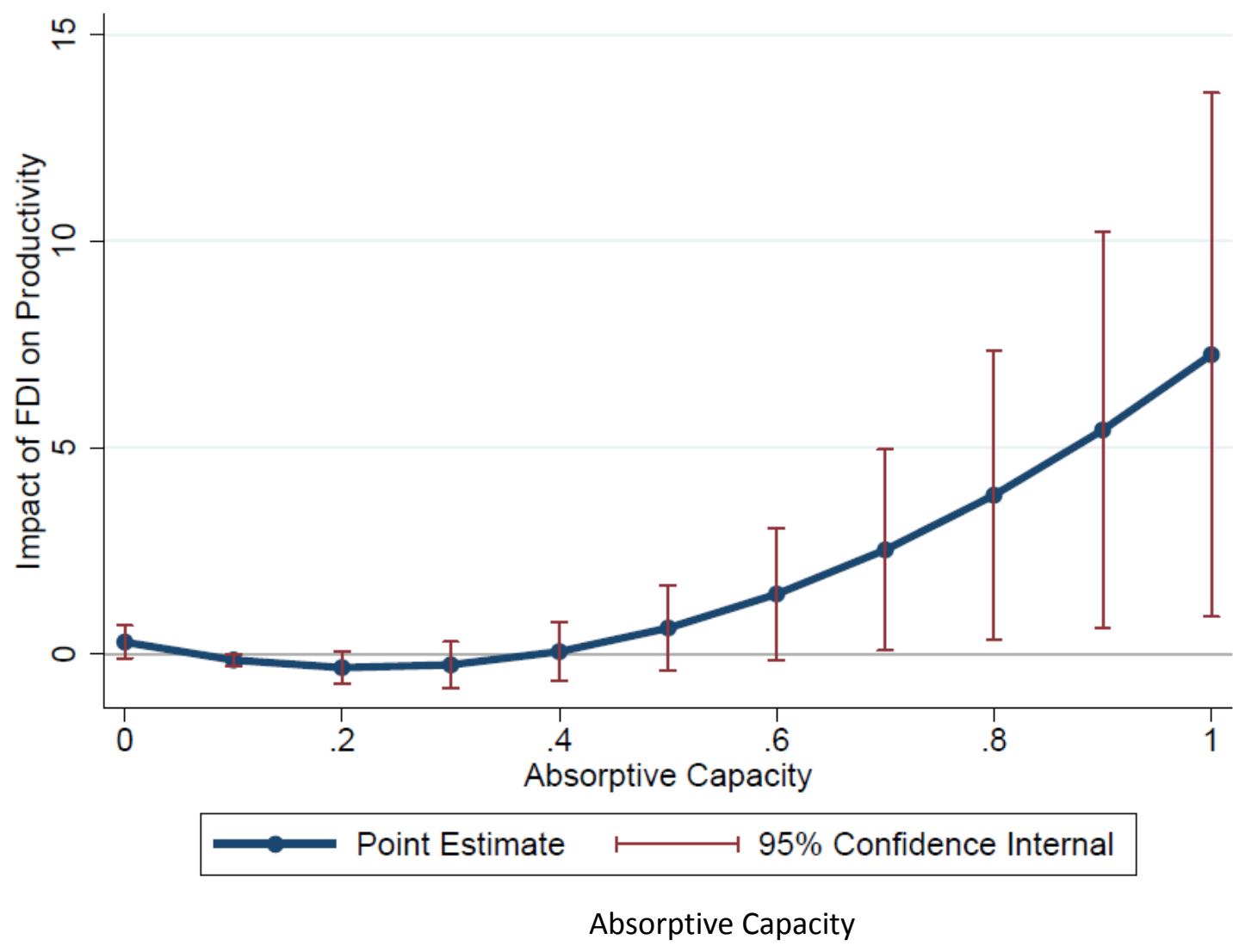

Note: The figure shows how the spillover effect depends on a firm's absorptive capacity using the estimated coefficients in column 3 of Table 7. 
Appendix Figure 2

The Effects of Absorptive Capacity on Vertical Spillovers

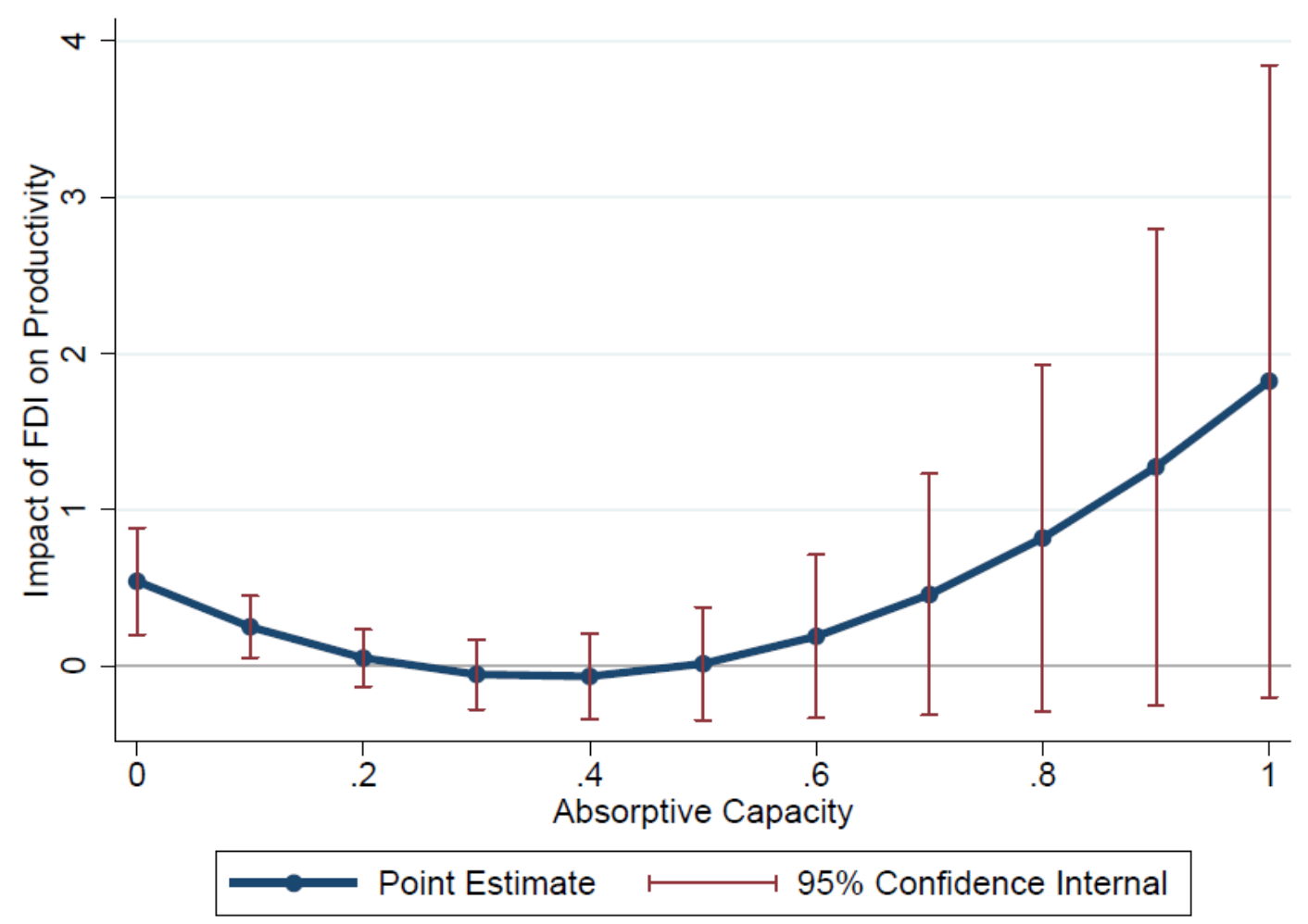

Note: The figure shows how the spillover effect depends on a firm's absorptive capacity using the estimated coefficients in column 3 of Table 7. 